\title{
The Role of the French State: Shifting from Supporting Large Tourism Projects like Disneyland Paris to a Diffusely Forceful Presence
}

\author{
A-M. d'Hauteserre \\ Department of Geography, University of Waikato, Private Bag 3105, Hamilton, \\ New Zealand
}

The French state, in its role as legislator, has sustained relations of production within the French economy because space can be selectively configured to promote economic, social, and environmental community goals. It tries to avoid that public value be held captive to private value or that developers bypass environmental legislation. In a country where the state is in the habit of regulating everything, it is not surprising that it should have taken charge of tourism projects. This paper will determine whether the relationship between public and private enterprise in tourism development in France, where the government has systematically encouraged such partnerships, has been successful. The paper will also show whether leadership provided by the public sector in areas not necessarily focused on tourism development is what helped push France among the most visited countries in the world. Decentralisation policy has driven the state to the backstage where it remains active to ensure the continued presence of France on the international scene. Although it is tempting to advocate a particular form of governance in supporting tourism development, most forms have evolved within specific contexts and would be resistant to radical transformations. A careful scrutiny of specific examples helps to illustrate possible effective changes.

\section{Introduction}

Economic success does not last forever. To remain vital, economies need continuously to assess their assets and liabilities and redefine their unique qualities, capabilities, comparative advantages and vulnerabilities. Capitalism's most lasting product is new landscapes, which, in many places, it has rendered impermanent, forever exhibiting a new repertoire. Such shifting landscapes created by multinationals in their quest for the best return on their investments illustrate the structural changes of the global economy which have, for example, led an American corporation to implant a major American artefact in the Francilian landscape. Does regulation through public authorities have a role in capturing circuits of capital that will develop tourism and create economic growth? Successful regulation means that capital accumulation is accompanied by social benefits (i.e. the capital circuit becomes geographically stabilised and sustainable, functioning as an economic locomotive, and the landscape is made more permanent). The free market is an indispensable element of democratic systems but it cannot resolve crises of accumulation when it lacks institutionalised rules for sustainable conduct. The creation and growth of sustainable regional economies result not just from atomised decisions of private productive firms, be they global or local, 
such as the Walt Disney Company, but also from a 'politics of space' at the national, regional and local levels (Storper, 1997).

This paper seeks to demonstrate that the articulated use of state regulation at all levels of governance can sustainably anchor tourism circuits of capital in search of profitable locations by offering them customised spaces. It will critically examine whether the relationship between public and private enterprise in tourism development in France, where the government has systematically encouraged partnerships with the private sector has been successful. Policies promoting physical redevelopment through public-private partnerships were heralded as the key to economic success (Fainstein, 1994) but regulation creates lags and rigidities which bloc the fluidity or flexibility of the market. The paper will also show leadership provided by the public sector in areas not necessarily focused on tourism development, is what helped elevate (and maintain) France as one of the most visited countries in the world, year in and year out.

Different investment choices and contrasting state policies lead to very different consequences, as the fates of Battery Park (New York) and Canary Wharf (London) have demonstrated (Fainstein, 1994). The implementation of the Disneyland Paris project in France would have been impossible without the planning culture and structures set up by the French government. Different organisations have different capacities, roles and responsibilities. There is the added pressure to perform well in a highly competitive dynamic market situation. Although it is tempting to advocate a particular form of governance in supporting sustainable tourism development, most forms have evolved within specific historical, cultural, legislative, economic and political contexts, and would be resistant to radical transformations. A careful scrutiny of specific examples can help to illustrate possible effective changes. Tourism, like centralised government, has a long history in France: it was first recognised as a separate activity in the 1700s. This paper, however, will examine the French state's interest in tourism after World War II only.

The paper has three main parts. Part 1 shows why it is still relevant to discuss national government intervention in tourism planning and development in France and describes the French state's interventionist policies. The French state long preferred the top-down approach in support of large projects. This situation is exemplified in Part 2 with a discussion of why the Disneyland Paris theme park was built in France. This project happened because it could be included in the Master Plan devised for the Paris Basin, and because of the structures set up to ensure the implementation of the plan. The many criticisms levelled at the French government for inserting this foreign project in the French landscape were answered by mechanisms which have since protected the area from unscrupulous activities the Walt Disney Company might have reverted to in free market conditions. The state, however, has withdrawn from interfering in many areas, in particular in large-scale tourism planning, in favour of a bottom-up, community-oriented perspective described in Part 3. Two forms of rural tourism are used as examples of local intervention. The state's retreat, though, is only partial and strategic. The state still supports enterprises and activities that reflect or enhance national interest or prestige. 


\section{Part 1: The French State and Planning}

\section{A. Planning and the nation-state}

In the United States, potential investments that are not directed at short-term monetary gain are often criticised as 'social' investments, even though all investment takes place in a social context. State intervention can mitigate and contain the conflict inherent in capitalist social relations ... otherwise capitalism could not avoid socialisation deficits, rationalisation failure, or spontaneity of economic crisis and sharpening of conflicts to the point of social and ecological catastrophe' (Altvater, 1993: 13). The free market is not the only or even the most sought after arena by private companies (even large ones) to invest in. Although it can be argued that the private sector usually dominates the private/public relationship through its command over investment choices, it depends heavily on public sector decisions concerning investment in infrastructure, tax policy, social relations and regulation of construction (Fainstein, 1994). Developers themselves have sometimes wished for more state intervention. Oversupply of built space is to noone's advantage. The Walt Disney Company, at least initially, requested the close cooperation of the French government to create its European theme park near Paris.

The nation-state may not be the scale at which future institution building is rooted (Bennett \& Estall, 1991; Peck \& Tickell, 1995: 26). The construction of supra-national organisations like the European Union leads them to encompass regions of similar economic activities within wider systems of political economic interdependencies. The European Union, by forcing similar norms, favoured France in its negotiations with the Walt Disney Company, for example, by preventing Spain from offering lower interest rates. Certain regions could also represent unique conjunctures within their national system. The European Union has been more active in promoting tourism since the late 1980s, but, whether it applies the older 'equity' philosophy or the more recent 'free market' one, most European aid funds would go to regions in countries other than France because of its higher level of wealth than Spain, Greece, Portugal or Ireland. The political system of capitalist society, however, was and is bound up with the nationality of the state. Borders mark the difference between inside and outside and thus delimit a national territory over which a state has sovereignty (Poulantzas, 1978) even if certain realities make national borders antiquated (e.g. multinationals, forms of pollution, drug trade). The Walt Disney Company could negotiate only with individual European governments in its search for a resort site, and not with the European parliament.

Governments are restricted in space and are constituted by the total amount of resources present in that space and by the quality of its environment. The question, then, is how to manage within the same space, events that are shaped by local decisions together with events that are shaped by outside strategies (Fainstein, 1990,1994; Gittell, 1994; Rencontres, 1992). The question also arises as to how to marry economic efficiency and social justice (Judd \& Parkinson, 1990; Storper \& Scott, 1992; Thrift, 1994). Many governments have identified planning as an appropriate device to address social objectives, environmental protection, and landscape enhancement. Beauregard (1990) and Friedmann (1987) emphasise the morality of planning, its goals of social justice and redistri- 
bution. They also underline that the planning role of system maintenance can be expanded to include even more features of social policy formation. Policy-makers have then attempted to capitalise on service-sector advantages, including new leisure activities and real estate development (planning for tourism has been attractive because tourist destinations combine these elements), as a way of dealing with otherwise intractable economic and social problems in the face of a continuing decline of manufacturing. All organisations involved in economic development aim to influence behaviour, not just governments.

\section{B. Interventionist policies of the French state}

The state is an ensemble of agencies of legitimate coercion capable of sustained purposeful action. The French state, in its role as legislator, has sustained relations of production within the French economy. With or without a master plan, housing, schools and hospitals will be required, as will networks for water, gas and electricity, together with public transit systems and roadways (Delouvrier, 1966; Ploegaerts, 1986). In other words, policy decisions, legislative measures and planning avoid future problems caused by otherwise disjointed and incremental responses. The French state and its representatives believed in state intervention and state planning. In 1956, the state started a programme of industrial decentralisation for which it created the Délégation à l'Aménagement du Territorie et à l'Action Régionale in 1963 (commission for land management and regional action). DATAR was the tool, until 1974, to redistribute the benefits generated by economic wealth through land development and land use policies. It concentrated on moving industrial companies out of Paris (200,000 jobs) generating 300,000 new ones in the Province between 1956 and 1974 (Rochefort, 1996: 48). It also developed urban plans (Schémas Directeurs d'Aménagement Urbain SDAU) for major urban areas and later for smaller ones. These plans included the implementation of New Towns based on ZADs (Zones d'Aménagement Differé).

In France, the government's concern with planning relies on effective control of the organisation of space. Planning has developed as an intellectual movement in France since the nineteenth century. This movement has considered that the public interest '... is the responsibility of the government to monitor, organise and encourage the construction of a container for society's and economic life' (GIE, 1993: 53). A committee for the expansion of Paris was established by the Prefect of the Seine as early as 1910 . However, it took the proponents of planning 50 years to convince the public and the legislature of the need to take the collective interest into account in questions of housing and land development (Gaudin, 1985). It did lead to the creation of the Prost Plan for the Paris area (1934), the first official plan to cover a major city, which served as a basis for the 1960 Plan pour le Développement et l'Organisation Générale de la Région Parisienne (PADOG). French legislators had voted the 1943 law establishing an authoritarian system of centralised, government controlled planning. It lasted for 40 years, and the 1967 Pisani law barely modified it. Between 1960 and 1980, France was flourishing economically and the future seemed assured thanks to state planning.

The PADOG was a mid-term plan (40 years) to control the growth of the Paris conurbation. It was based on more than 15 years of dialogue with local authorities. Three of the main urban nuclei that it suggested creating in the suburbs now 
exist, notably La Défense, West of Paris. The present Regional Express Rail (RER, one line of which gives access to Disneyland Paris) and motorway networks follow the palimpsest it had set up. It also provided the basis for planning public utilities and amenities in the suburbs. It was part of an attempt to remedy the functional inadequacies of high rise apartment blocks. The decree of 31 December 1958 founded priority urban development zones (ZUPs, Zones Urbaines Prioritaires) one of the first major instruments for long-term planning, ancestors of deferred development zones (ZADs) and other mechanisms which enabled the government to integrate the Disneyland project in the Paris Basin. By the mid 1960s, it became imperative to anticipate, stimulate and channel development rather than halt or constrain growth. Policy-makers no longer refer to 'plans', which impose a precise and rigid pattern on maps, but to schémas directeurs, which organise future development along major axes. These axes are chosen on the basis of operational urban development policies. The conclusion was also reached that a balance between housing, employment and amenities could only be achieved through large-scale, long-term projects. New Towns were the cornerstone of the new planning philosophy.

The Paris Basin was the first to benefit but the DATAR extended the planning principles to the provinces. Such control was becoming essential because of the very precise locational demands of certain industries and the critical situation in traffic, housing, and facilities in the majority of great conurbations. The idea of entrainement (stimulating growth in chosen areas) was introduced as early as the third plan (1958-61) and embodies a wide range of objectives such as the creation of the most conducive spatial framework for the attainment of rapid economic growth, economically efficient means of service provision, or the acceleration of the diffusion of innovations into backward regions. The French New Town project was established to also solve two of the main problems of planning: purchasing adequate land resources and avoiding chaotic urbanisation of rural areas (Schéma Directeur d'Aménagement Urbain de la Région Parisienne, SDAURP, 1966). Although it was not aimed at capturing tourism schemes, this project could accept varied investments, including tourism directed ones, if they facilitated the economic growth of the New Town.

\section{Planning for tourism development in France}

Planning and development in France have always included tourism (CREDOC, 1992; Py, 1996), which is considered from a broad perspective, not just an economic one. International tourism symbolises globalisation. France has always preferred a proactive role to promote its international presence. It has also recognised the embeddedness of tourism in societal and global processes. The French national Sixth Plan directed 'the opening of our economy to the outside world' as its first priority (DATAR, 1970:59), an initiative that enabled it to consider investments in the Tunnel under the English Channel (or Chunnel), and to accept foreign direct investments like the Disneyland Paris resort. France has thus provided the enormous public funding necessary for the super express railway system links to the Channel, integrating them in the French transport system so they will contribute to the country's economic growth. The state in Great Britain has refused to fund similar links on its side of the Channel. 
The number of foreign visitors to France reached the 70 million mark in 1998, 60 million of whom came from Europe (Direction du Tourisme, 1999). Their destinations and those of domestic visitors are unsurprisingly diverse given the size of the country and the variety of its landscapes. Tourism employed 619,521 people in 1997, or $2.7 \%$ of the national labour force, and provided $5.1 \%$ of the gross national product (GNP). Total consumption by domestic and international tourists reached FF612.5 billion in 1998 (Direction du Tourisme, 1999). The French spend $1.7 \%$ of all their private consumption on tourism (domestic and international). Americans spend only 1\% and Norwegians 7\%. In 1990, investment in tourism represented $4.1 \%$ of all investment in France (Durand et al., 1994). A little more than half came from the private sector, $65 \%$ of which went into lodgings (one-quarter to hotels and a little less than three-quarters to second homes). One-third of this investment in lodging went into major maintenance (Durand et al., 1994). Agribusiness exports and tourism help compensate the French trade deficit, since 1969 for tourism, and in increasing amounts. Tourism contributed FF71.7 billion net in 1998 (US\$11 billion) (Direction du Tourisme, 1999).

French state actions can be divided into three main areas: regulation, financial support, and land development. Tourism policy is overseen by several ministries besides the one so nominated: Exterior and Interior ministries define trade and commerce regulations. The Social Affairs and Work ministry determines employment conditions. Rural tourism is dependent on the Agriculture ministry. Major infrastructural investments for tourism projects are often made as parts of National Plans by ministries other than the tourism one. In the Xth Plan, the Ministry of Tourism was responsible for only $27 \%$ of all funds allocated by the state to tourism. This division could indicate a relatively low priority accorded tourism development. The state, however, has pursued a consistent policy direction even if it has not always been clear.

The state's interest in tourism has a long history in France. Originally, in the nineteenth century, the state was interested in the 'money spent in the country'. Legislators long favoured tourist arrivals and spending while they restricted foreign travel and spending by French citizens. A National Tourism Office was created in 1910, and in 1936 tourism had its own state secretariat. The first national plan (1949-52) included the promotion of 'destination France' through the extension of the road network, the improvement of rail service, the construction of 20,000 hotel rooms and the refurbishment of 180,000. Some investments targeted specifically for the development of tourism were included in the Vth Plan (196670). Tax legislation is also used to encourage tourism investment (Journal Officiel, 1994). The best known is the Loi Pons, in favour of developments in the DOM, TOM \& POM (French overseas départements, territories and pays in the North Atlantic, the Pacific and the Caribbean). Rural tourism is supported by similar measures to encourage farmers to remain active on their farms.

The French government tries to avoid that public value be held captive to private value or that developers bypass environmental legislation. 'The difficulty was not in finding space [for tourism developments] but in organising it to avoid its degradation' confirm Durand et al. (1994). The state carried out reforestation, mosquito eradication, water distribution and a variety of other programmes throughout the Vth Plan. It was the first time that the link between tourism development and the need to protect the environment was underlined 
(Rapport Général, 1965). The decision was confirmed in the VIth Plan (1971-75), which emphasised the need to counteract negative environmental impacts of tourism but did not halt the development of the latter (Rapport, 1971). For the French state, protecting nature is to prevent new activities from penetrating certain rural areas too rapidly, while preserving the quality of open spaces in those threatened by desertification (Rochefort, 1996).

The French state recognised that landscapes are the major resource of tourism that thus commodifies public free goods. The protection of nature, which includes landscapes, was embodied in the law of 7 January 1983, and reaffirms the importance of nature as part of French society's heritage. It became necessary to protect more landscapes from negative exploitation and degradation as illustrated by the Loi de la Montagne of 1985, and the Loi du Littoral of 1986. The state established these planning programmes to encourage the creation of durable landscapes and to avoid premature dereliction through easy abandonment. Landscape includes the geographical meaning of 'physical surroundings' and the ensemble of material and social practices: it is the entire panorama. It connotes a contentious, compromised product of society, on which powerful institutions have a pre-eminent capacity to impose their view: public entities as well as capital, not just the latter.

National parks, created on the basis of a 22 July 1960 law, include not just natural but also 'cultural features that, combined, offer respite, leisure opportunities and tourist attractions, and which thus deserve to be both protected and organised' (Durand et al., 1994:41). The state has sought to enhance the quality of landscapes (paysages), both natural and cultural and found that protecting historically relevant cultural sites could lead to cooperation across local authorities. Heritage site development is also incorporated in economic development programmes. The emphasis, the French state has affirmed, is on ensuring, or at least not sacrificing, socially equitable and environmentally sustainable development on the altar of job creation and capital accumulation to avoid that improvement explicitly reject the social variety of habitation and functions or explicitly seek security by exclusion (CFNG, 1996).

\section{State tourism development projects}

The state has supported other tourism projects besides Disneyland Paris through land management agencies linked to DATAR, in particular through tourism government missions. These missions grouped members of different ministries to ensure the synchronised development of coastal areas to attract more foreign visitors as well as domestic ones. One concerned the coastal area of the Languedoc-Roussillon along the western Mediterranean Sea - MIATLR (Mission Interministérielle d' Aménagement Touristique du Languedoc Roussillon), the other the coast along the Aquitaine, on the Atlantic Ocean south of Brittany MIACA (Mission Interministérielle d'Aménagement de la Côte Aquitaine). They were created in 1963 and 1967 respectively, for a period of 20 years each.

MIATLR constructed 7 coastal resorts and 14 marinas. It reforested thousands of hectares, eradicated mosquitoes and supported the construction of limited access roads to link the new resorts with the national road network. It transformed this originally inhospitable coastal zone into spaces for the relaxation of domestic tourists, $6.7 \%$ of whom visited the area in 1970 . In $1990,12.1 \%$ of domestic tourists 
frequented the area. Total visitor numbers increased from 525,000 in 1965, to 14.4 million in 1994, 27.5\% of whom were foreigners (Baleste, 1989; Clary, 1993; Ministère de l'Environnement, 1995). It aimed to diversify the economy of the region until then too reliant on wine production, providing 30,000 new jobs by 1985. The economic effects have been seen as essentially positive. It also successfully relieved some of the congestion along the Côte d'Azur (Tuppen, 1991).

MIACA subsidised a supply of 200,000 beds, doubled the supply of camping sites and participated in the development planning of several areas, but it encountered resistance against governmental purchase of land from local communities and especially from local residents who owned forested estates: they wanted to preserve their large hunting domains. The government could not then protect the area from land speculation. The project to link the various water bodies of the area by a canal had to be abandoned for technical reasons while many small private developments and secondary homes sprouted along the coast at the expense of social programmes. Protection of the dunes has suffered too (Baleste, 1989; Clary, 1993). The area still attracted $8.8 \%$ of domestic tourists in 1990 up from $7.5 \%$ in 1970 (Clary, 1993).

The state has disengaged from major tourism projects along the Mediterranean coast since the late 1980s and relies on the application of national legislation by local governments. One of these laws (10 July 1975) did create a national Conservatory of Lake and Sea Shore Space (Conservatoire du Littoral et des Rivages Lacustres) to facilitate the acquisition of sensitive coastalareas and to reduce speculative hoarding, in response to criticisms against increasingly visible damage to the environment. Between 1976 and 1994 42,284 ha had been bought and 51,222 as of 1 September 1997, representing $705 \mathrm{~km}$ of shoreline. Some coastal landscapes have been restored in partnership with local authorities and private donors. Other laws guarantee free public access to all beaches whether along the sea or along a lake shore: a three metre-wide swath for passage along the beach and paths from the main public ways to the beaches must be provided through private land along the coast (Lanquar, 1995). Corsica has refused all forms of state tourism planning for its coastal areas.

From the early 1960s, the notion of culture became increasingly idealised in public discourse and came to replace leisure. The state has also been more preoccupied to guarantee the security of its citizens and of public order than to organise its leisure activities. Even though French economic prosperity began to be seriously threatened in the 1980s and unemployment and social costs were deemed to be far too heavy, France held its original perspective and continued to increase its spending on cultural matters (Poujol, 1993). Nearly half was devoted to conservation and to the promotion of the cultural heritage. The state also invested heavily in large projects such as the Pompidou centre, the Musée d'Orsay, the Louvre renovations, the Bastille Opera, and, most recently, the mega National Library. They have all become major tourist attractions: for example, Orsay received 2,724,000 visitors in 1998.

The Ministry of Culture created in 1959 (for André Malraux) has had the mission to conserve, rehabilitate and enhance the national cultural heritage and to broaden its audience. Since the mid 1980s, the state and local authorities have played a major role in the touristic development of this heritage, in response to strong demand. Cultural tourism brings in 15\% of all tourism induced revenues 
and provides 145,000 jobs. The government has tried to inflect a sustainable form of development to reconcile site protection, touristic exploitation and economic growth. Such a delicate balance is perpetually threatened by severe competition and increasing financial requirements. Sustainable development is also based on contemporary models and concepts, which can rapidly become obsolete. It is difficult to integrate future mutations or ruptures. Sustainable development does have a pedagogical function, to sensitise local residents as well as tourism operators and government representatives and to encourage these groups to negotiate when their interests and beliefs diverge (Patin, 1997).

Cultural tourism programmes in France have always included both nature and culture following a long history of protection of the country's cultural heritage. The first law for the conservation of historic monuments was established on 30 March 1887, and on 13 December 1913 a new law established the norms for registration as well as a classification system. On 2 May 1930, a law was created to extend the registration and classification system to any natural site that is picturesque, artistic (was painted by an artist), historic and legendary, or even scientific. Laws voted in 1983 and in 1993, ensure the protection and restoration of urban or rural spaces that demonstrate a high architectural or landscape quality: these ZPPAUP (zones de protection du patrimoine architectural urbain et paysager) exist in 85 different areas, covering $5500 \mathrm{ha}$. Protected sites belong mostly to local authorities $(61 \%)$ or to private entities (29\%) (Patin, 1997). The state owns only $6 \%$ of the sites and monuments managed by the Caisse nationale des monuments historiques et des sites, which was founded in 1914 and the DATAR, through its mission of conceiving and implementing national policies of development, is one of the main agents involved in the touristic commodification of French cultural heritage.

Bauer (1996) reproaches the French state for under representing ethnographic aspects of its national heritage. Elements of popular or folk culture are conspicuously absent from the list of state recognised heritage attractions. This may be due in part to the strong interest by the French state in asserting a single national culture in response to devolution by Brittany, Corsica and Basque country (Wood, 1997). Recent efforts, responding to the demand for more rural based tourism, provide visitors with eco-museums, where past practices are animated among collections of artefacts, festivals and picturesque villages (often protected under the ZPPAUP law). Gastronomy has been most popular: Versailles hosted a culinary exhibition, Tables royales de Catherine II à Marie Antoinette (Royal tables from Catherine II to Marie-Antoinette), at the end of 1993 and into early 1994, which accommodated 299,055 visits.

\section{E. Social tourism}

France is one of the few countries in the world that has developed such a sector, which provided, in 1994, 9\% of all tourist beds and serviced 1.5 million people (Durand et al., 1994). The ability to take vacations away from home is still not a reality for a large part of the French population, either because it lacks sufficient disposable income or because destinations are not equipped for that clientele. The percentage of the French who could not go away for a vacation has decreased over time from $56.4 \%$ in 1964 to $31.3 \%$ in 1996. Three main reasons prevent them from travelling: deliberate choice (though often shadowed by 'economic' worries), budget constraints $(53 \%)$ or family constraints $(30 \%)$ 
(Observatoire, 1998). Physically challenged people also have difficulty finding accommodations that are accessible and that can cater to their needs.

A number of instruments exist to facilitate such departures but the government is examining their validity. Until 1984, the government subsidised the construction of family lodgings and holiday villages reserved for the beneficiaries of social programmes. Very few were built between 1985 and 1990, so that $60 \%$ of them needed to be renovated by 1990 and $30 \%$ had to be demolished (CEDAET, 1992; Observatoire, 1998). The government continues to support the training of employees required to run these establishments. The political aim is still to reduce social inequities and to minimise social exclusion. The groups denied vacations away from home have changed: young working class families have been replaced by those on long-term unemployment, the elderly, as well as families or individuals not socially integrated. The government is also examining access to tourist destinations by handicapped people.

Financial aid (in the form of travel stamps) from the government to families, instituted in 1982, amounted to FF887 million (US\$1774.4 million) in 1994, and FF1.92 billion (US\$384 million) in 1995, and benefited some five million people (Py, 1996). The government has encouraged the use of travel stamps because it also generates multiplier effects. The checks mean money is spent on a variety of economic activities which, in turn, have fostered a threefold increase in spending. The handling of the state funds has been decentralised since 1986, so the organisation of vacations is in the hands of regional Caisses d'Allocations even if they are still funded by the state. Regions now have to finance much of this form of tourism so that only four had retained it in their contract with the state under the IXth Plan (1984-1988). Much of the help now goes to participation in local leisure activities that permit better social integration within the community rather than to vacation travel.

Social tourism long relied on voluntary labour. The problem today is to reconcile social aims with economic viability since the state is reducing all subsidies. Various nonprofit associations managed 285,000 beds in 1993, or a little less than $3 \%$ of all tourism beds. Only Belgium and Denmark, within the European Union, also provide this form of tourism, but they each offer one-tenth (Belgium) and one-twentieth (Denmark) the number of beds. Demand for social tourism seems to be more seasonal than for other forms of tourism partly because volunteers are tied to school vacation schedules but mostly because the sun, sand and surf remain major attractions. Some of the structures have been used to foster economic development of the surrounding area since they are located in regions less frequented by more wealthy visitors. Because demand for tourism products has changed, nonprofit associations have had to compete with other tourism organisers to attract visitors. For some of these associations, this has led to the loss of their nonprofit status.

\section{Part 2: Disneyland Paris}

\section{A. The conditions for a French state/Walt Disney Company cooperation}

The Walt Disney Company had been looking for an overseas location for new theme parks since the mid 1970s. It had been dismissed by the French government in 1976. By the early 1980s, comforted by the success of its franchise in 
Japan, it had conceived the notion of large real estate developments based on complete tourist resorts (Flower, 1991). 'Disney is a real-estate enterprise which must exploit its holdings to the last square inch, without giving competition the slightest break' affirmed its then CEO, M. Eisner, in a press conference defending the company's penetration of the French market. Walt Disney Company's plans which ambitiously combined tourist and urban functions, i.e. theme parks and other attractions together with offices, hotels, retail shops, housing, and sports complexes, required considerable space. It had already recognised the significant advantages of a site in the New Town of Marne-La-Vallée: available acreage and easy accessibility to the whole European market.

The spatial mediation of cultural consumption, just like ind ustrial production, affects the redistribution of benefits among social classes and explains the direct interest of the French government in a Disney theme park, and its offer of the Marne-La-Vallée location. For the French government, Disney's project would create an urban growth pole economically independent of Paris. Gaston Deferre, the Mayor of Marseille, had hoped the Walt Disney Company would choose a site in Camargue since' '... such a large project would represent a major economic boost and many profitable investments for the region, a shot of oxygen for construction and public works' (quoted in Burlet, 1987). The competitive edge of the French government to capture the Disney investors was by means of product differentiation, offering a space they enhanced through design and designation. Public authorities must have a very long-term vision to anticipate development needs decades ahead, to control the space required and its accessibility. It is also a matter of the cultural context, whether it favours a neo-liberal versus a more socialist approach to government.

The French government is renowned for its complexity, its bureaucracy, and its layers of state and local governments, in spite of which very practical solutions were devised. Altogether there were 36 different delegates on the French side of the table when negotiations started since the French government was extremely secretive about its dealings. It encouraged the Walt Disney Company to make as many contacts as possible among the various public authorities, and to play them against each other until Michel Gifaud, responsible for the region of Ile de France, demanded that the state designate one representative to speak for all. The various parties to the French side of the negotiations eventually agreed upon a single negotiator. Continuity in policies and in the negotiations was maintained through various government (and political party) changes (Rencontres, 1992).

The main characteristic of the Disneyland project is that it is a public-private partnership (i.e. the government and the private company each assume those risks and responsibilities that are specifically theirs). This is fundamentally different from a mixed economy where the government and the private company take on risks and responsibilities together. A contract was signed, at the behest of the company, on 24 March 1987, between the French government (six public partners: the state, the Ile de France region, the Seine et Marne Département, the Régie Autonome des Transports Parisiens (RATP), EPAMarne, and EPAFrance - see explanations on these last two below) and a private society that the Walt Disney Company would create, Eurodisney SCA (Société en Commandite par Actions, a company listed on the stock market). This Convention 
(1987) was signed to permit the development of 1943 ha, according to a detailed plan (mise en oeuvre opérationelle through a Projet d'Intérêt Général) that would follow in spirit and to the letter the planning philosophies of the state described above. The Convention determines the duties and responsibilities of each partner, not just those of the French government, which critics have often confused with concessions to the Walt Disney Company.

In 1992, the Walt Disney Company criticised the rigidity of the convention. It won some minor concessions, but none concerning the timetable or the urbanistic demands. Basic laws of urbanism, which are embodied in the Projet d'Intérêt Général (that part of the plan that governs land use development by Eurodisney SCA) cannot be modified, whether they are included in a contract or not. The French government never lost control in this domain. EPAFrance was created (on the basis of article L321-1 of the Code de 1'Urbanisme) specifically to protect the public and the local governments, who would be heavily impacted by the project. This Etablissement Public d'Aménagement (EPA) would also guarantee the coherent development of such a large area through a well-coordinated public sector. The boards of trustees of the EPAs include mostly elected officials. The EPA in charge of developing the New Town of Marne-La-Vallée (EPAMarne) continues to maintain the balance sought for in the original Convention and to remind Eurodisney SCA of its obligations. Minor modifications must be compatible with the letter of the Projet. Major modifications would require the renegotiation of the Convention and of the urban plans the Projet d'Intérêt Général is based on (EPAFrance, 1994; Rencontres, 1992).

Marne-La-Vallée is such a large New Town that it has been divided into four sectors. Disneyland is in sector IV. A new Etablissement Public d'Aménagement was created to direct the development of sector IV and thus of the Disney park, EPAFrance. The government invested FF2.7 billion for the development of the park for a total private investment of FF23 billion. Some of the infrastructure built with this capital services more than the park. The Regional Metro Lines - RER service sectors III and IV; the Trains à Grande Vitesse - TGV, fast trains - station is to be used by the whole of the New Town; water supply, sewers, highway exits were constructed for the whole of sector IV. The government had also commissioned a cost/benefit analysis to help in its decision-making, as well as an environmental impact statement (SETEC, 1985, 1986, 1987; EPAMarne, 1988; Institut d'Aménagement et d'Urbanisme de la Région d'Ile de France (IAURIF), 1988).

\section{B. Structures that governed the implementation of the Disney project}

Policies were adopted in the early 1970 s to guarantee the availability of the needed acreage even though the Walt Disney Company project was unknown and the company signed a letter of intent only as of 18 December 1985. A policy of anticipatory funding or long-term investment under government supervision was initiated together with land price control policies to channel development in the periphery of urban areas under the DATAR. Deferred development zones, or ZADs, permit land to be pre-empted long before it is purchased, 8600 ha in the case of the New Town of Marne-La-Vallée (GIE, 1993). These were linked to immediate public land purchases of exceptionally wide scope (4770 ha in Marne-La-Vallée), in order to preserve future options and subsequently re-invest the increased value of the land in the construction of the new towns. 


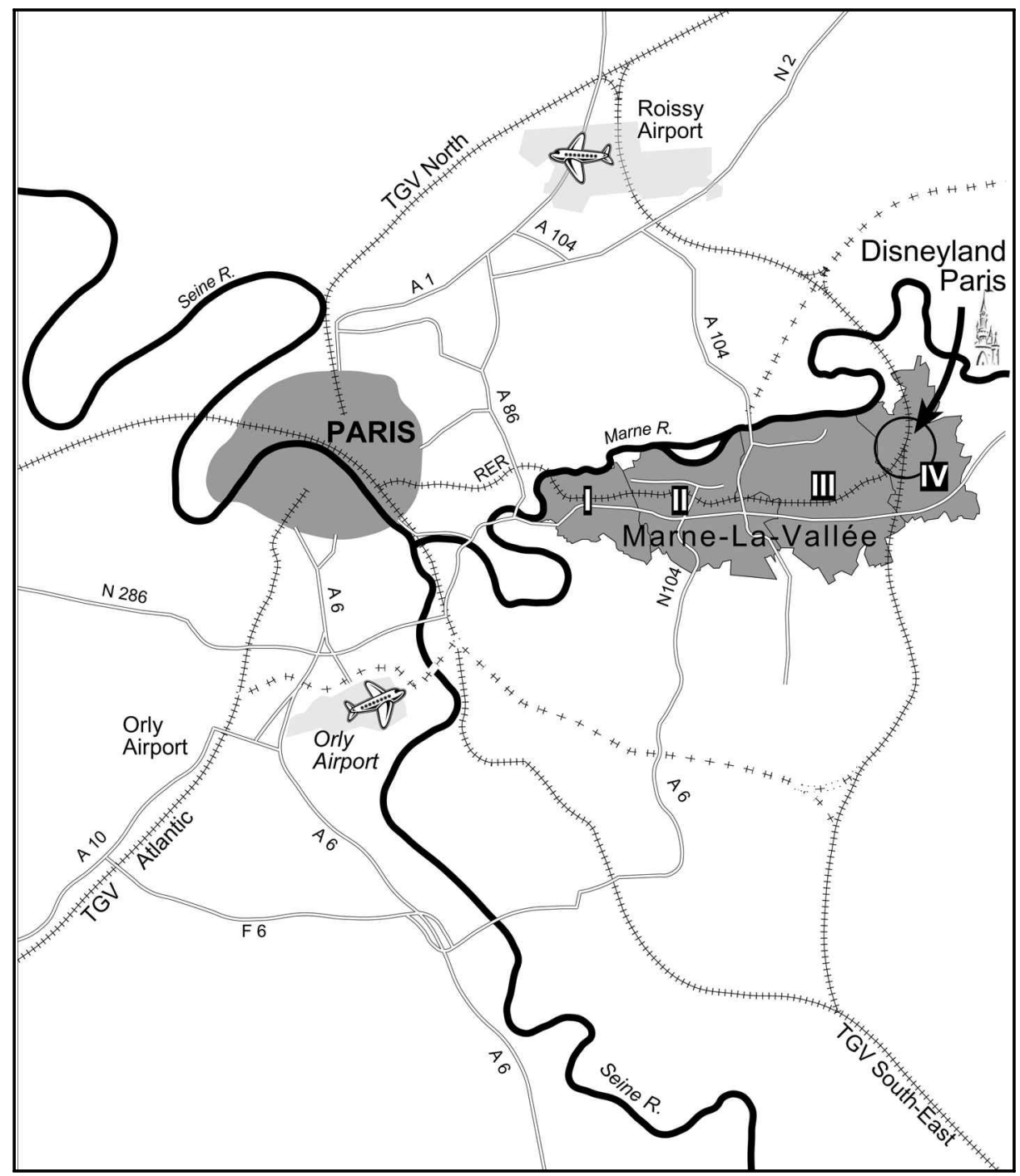

Figure 1 Location of Disneyland Paris in Marne-La-Vallée

These initiatives were made possible by the creation of the land and technical service agency for the Paris region (AFTRP), which was established in 1961 (Livre Blanc, 1992). Because the government was quick to pay for the land, compulsive purchase was avoided. Similar plans were adopted in New Towns and other development projects elsewhere in France.

An issue confronted by the two sides was the preferential price at which Disney could buy the 1943 ha, especially since some writers believed that the company could then sell or rent the land as it deemed profitable. Some critics also declared that the government had to buy more land than the company would ever pay for. Eurodisney SCA (the owner of the Walt Disney Company project in the Paris Basin, project which will eventually include much more than the 
Disneyland or Magic Kingdom Park) has tried several times to replace the EPA, but French laws do not allow private companies to initiate development. EPAFrance represents all public authorities in negotiations with Eurodisney SCA. The size of the Disney project and the amount of land it required, one of the largest development projects in France in the 1980s, was another major source of criticism (Lanquar, 1992). Walt Disney Company chose the Paris Basin (in spite of its damp cool winters) because the French government was the only European one that could readily provide such a large acreage.

The EPA is the master builder of the secondary infrastructure, for the French government, not simply as Disney's proxy. Its work is defined by the revenues it raises from the improved lots it sells to the Walt Disney Company, or to other investors in this sector of the New Town of Marne-La-Vallée. The price of individual lots is based on four elements:

(1) The agreed basic price of the agricultural land (US\$8000 per acre). That is the purpose of the New Towns who purchase land tracts 25 years before any development appears, and thus without assurance that it will occur, to buy land before its value has appreciated.

(2) Cost of the secondary infrastructure built by the state or its representative (for a total of FF1.5 billion in 1995).

(3) Financial costs: the agreement restricts the land's price from increasing with the inflation rate even though Disney was given 20 years to complete all the land purchases. Nonetheless Disney was to cover the financial expenses of maintaining idle real estate to alleviate their fears of uncontrollable price increases.

(4) Expenses for general improvement (EPAFrance, 1994; EPAMarne, 1987). Thus, $1+2+3+4$ represents the total amount charged Eurodisney SCA, FF530m², or an average of $\$ 400,000$ per acre (not $\$ 5000$ as mentioned in Flower, 1991:208; Grover, 1991; Lipietz, 1987;Smadja, 1987). Eurodisney SCA also contributed payments towards the TGV station (FF200 million), the RER station (4 million) and the national electricity provider (EDF) for underground high voltage cabling (20 million) (EPAFrance, 1994).

The French government set up regulations to ensure that speculative hoarding would not occur. The timetable of development was the foremost concern of French authorities. The state provides the secondary infrastructure necessary within a predetermined timeframe, and its cost is included in the selling price of the land. The French government has always provided public regional and primary infrastructure in all the New Towns. Should the Disney Company have withdrawn before the opening of the Magic Kingdom, or had it closed its doors in March 1994 if negotiations for the financial restructuring of the venture failed, the infrastructure would have remained as support to other investors in the New Town. The Company accepts to develop specific plots of land, within prescribed time limits, following urban and architectural directives (for example, housing and hotels must offer different levels of accommodations). Once EPAFrance has made an offer, the company must respond by a pre-established deadline. In case of delays, Eurodisney SCA loses rights to one-third of the land not developed by the due date. Eventually, it can lose all of its rights (EPAFrance, 1994). 


\section{Was the Disneyland Paris project worth capturing?}

Most publications on Disneyland Paris in the 1980s and early 1990s denote how a capitalist corporation seemed to dominate transactions with public authorities (Walker, 1995), and how the French government seemed to have bowed to the Walt Disney Company's every demand (Flower, 1991; Grover, 1991; Lanquar, 1992; Lipietz, 1987). It represented an 'unquestionable national surrender to a private foreign power' for Smadja (1987: 98). Had the French state opted for a simulacrum of urbanism in the eastern part of the Paris Basin? Plans had been submitted to the public. Paul Delouvrier has painstakenly tried to demonstrate that the planning process in France was democratic from its inception, through the use of public opinion polls and the publication of population projections and of the needed infrastructure (GIE, 1993: 35), even though from the state's perspective, the practice of the democratic process, of interactive participation, can reduce the efficacy of a project. Plans for the Paris Basin 2000 project were presented in 150 public lectures, in mass media reports and in four books, but democratic interactive participation was not encouraged. Consultation had occurred with the 130 mayors of the area and their 20,000 councillors, various trade and ind ustry organisations and associations of architects and town planners.

Local developers recognised that Disneyland Paris seemed to represent a fantastic opportunity. On the other hand, 'as it stimulates large numbers of projects, it is increasing the risks in the region, for hotels and other services: risk of excess capacity, first, risk that the resort's spillover effects be less than expected ... leading to profits for Disney only' declared a critic (Robert, 1990). The company offered an injection of capital and of specific activities that can encourage other investors to build the missing elements. As an official explained: 'Disney guarantees us notoriety and invaluable credibility with international CEOs. The Walt Disney Company could not have chosen Marne-La-Vallée by chance' (Vachez, 1989). Investment is the motor of growth, it ' . . . is the critical element in the addition of new capacity, the application of new equipment, the opening up of new product lines, the creation of new firms, and so forth' (Walker, 1995: 189). The government's New Town Plan for Marne-La-Vallée has scheduled a more balanced form of development for the park's periphery, a diversified urban node, which includes a university. The objectives of the plan have been realised in the total new town of Marne-La-Vallée (e.g. Cité Descartes, in sector III houses the university).

Criticisms often spring from a notion of 'capital versus the regions', where foreign corporations are seen to exploit available resources and then abandon the area when resources are exhausted or cheaper alternatives are identified elsewhere. The Walt Disney Company could not just close the doors of its Magic Kingdom Park when it was threatened with bankruptcy in 1994. The Convention that the company signed in March 1987, stipulated that if the project were abandoned by the company before completion, it would have had to pay the EPA to bulldoze all that had been erected to clear the site for other urban investments. It also had to offer financial guarantees over three years to the French government to indemnify local authorities if it abandoned its project (EPAFrance, 1994). The construction of a TGV station close to the resort was designed to reduce crowd- 
ing in Paris stations, and was constructed at the request of the French government; it was not a response to a company command.

Some critics declared that Disneyland Paris could have been a growth pole without government intervention or that other economic activities would have engendered the same kind of spillovers (Eudes, 1992). The company could not have assembled the acreage it required in the private market. Some of the major communication links were planned for construction and were not built at the behest of the company. Such infrastructure, however, would not have been available for at least a decade in the absence of plans for New Towns and of the requisite partnership between the Walt Disney Company and the French government. The company might then have been swayed by the sunnier climate of Spain. If the very point of a New Town is to attract inhabitants and businesses to a place to which they would not otherwise have come at that particular time, it is obvious that they will come only if attractive amenities are provided from the very start. Substantial front-end investment is necessary to create a critical mass. Fainstein $(1990,1994)$ demonstrated how the Docklands project failed because of the British government's refusal to bolster the enterprise, including the construction of infrastructure in advance of development.

There were some questionable concessions made by the French government, especially in financial matters. However, many of these the company had to relinquish at the time of the financial restructuration of the resort (March 1994) without which it would have had to close. The greed of the company (excessive debt leverage) caused much of its financial distress. The restructuration happened only because the company's short-term views were embedded in the French government's long-term plans. The Convention rescued the resort from bankruptcy. Michael Eisner postured for Wall Street, swearing to close rather than back down. The Walt Disney Company would not only have suffered a major blow to its image, it would have faced huge costs (bulldozing its park). The European banks did not feel as pressured during these negotiations. The axiom that ' ... if localities are on the march ... it is to the tune of globalizing forces ... a process in which local stability is far from guaranteed' (Amin \& Malmberg, 1994: 242) was denied in Marne-La-Vallée by the Convention, part of the French government's development tools.

\section{Criticising the interventionist role of government}

Criticisms listed above are addressed against specific actions of the state that seemed to give the Walt Disney Company, a foreign entity, unfair advantages. The state had taken measures to counteract such consequences so they were minimised. None of the criticisms, however, targets the policies that directed or dictated those actions nor do they provide true solutions. The idea of state planification, the objectives of the National Plans are never deconstructed or criticised. The (political) distribution of power resulting from the cultural constructs of the policies implemented by the state is never questioned. Policies can have major impacts on the economic, cultural, and social organisation of the targeted area. No criticisms address all of these consequences for the eastern part of the Paris Basin. The production of touristic spaces competes with other functions and other uses of space. As one form of territoriality is imposed, those included get confronted to those excluded or hardly integrated who seek to gain 
access to the newly defined power structure (Violier, 1999). No critic, for example, investigated whether plans for the New Town displaced long-term lower class residents of this region. The critics of the cultural impact of a foreign icon in Marne-La-Vallée were concerned with French culture in general, not its local manifestations, or facilitation thereof. Environmental consequences were hardly mentioned (d'Hauteserre, 1999).

Foucault has denounced how 'political technologies' have been used by the state to conceal its own operation. They have effectively deflected the critics of the Disneyland project from discovering who really benefited from embracing that project and who lost. Individuals who participated in decisions to implement the Walt Disney Company project were able to objectify the need for planning through the application of universalised ideas or objectives. The language used attempted to persuade the French public of the necessity to control its economic development through land use decisions rather than inform it. The position presented by the representatives of the state was 'held to be exemplary in some way' (Apthorpe, 1997:45). Who can oppose ideals of 'equity' and 'environmental protection'? The display of expert knowledge collectivised responsibility for the decisions adopted, circumventing direct critiques. The regions that have signed cooperative contracts with the state within the framework of the XIth Plan, reiterating the state's original position, have all assigned tourism the role of stimulating economic and employment growth in their area, even where tourism had been a minor activity.

Few criticisms have been published since the financial restructuring of Eurodisney SCA. Studies about its spillover effects confirmed its positive contribution to the local economy and to government coffers at all levels (d'Hauteserre, 1997). The company itself recorded profits only after 1995 and these have grown slowly since, muting all complaints about excessive earnings. The company had also complied with many of the directives of the Convention, purchasing and hiring within the Paris Basin (Articles 22 and 23 of the Convention). It also collaborated with the local unions about its demands for personal grooming, dress code and wage scales, and perhaps 'left intellectuals, if not actually embracing capitalism as the best of all possible worlds, hope for little more than a space in its interstices and look forward to only the most local and particular resistances' (Meiksins Wood, 1995: 1). Assessing the array of forces that cause change, determining how one can intervene, and imagining the kinds of possibilities that should be made realities are difficult propositions in the best of times. The current backlash against affirmative actions, immigrants and feminist movements, together with the surge of fundamentalism and of nationalism across the world, make energised critical analysis and oppositional politics extremely difficult.

Partnerships between the private and the public sector on the French model have attracted attention. A comparative study was commissioned by DIFU to determine their relevance for Germany (Ascher, 1994). Some partnerships have sprung up in other countries. Bassett (1996) and Hastings (1996) describe some of those in existence in Great Britain. These have been considered 'fundamental' to the success of urban rehabilitation projects by the government although it has not explained why. These partnerships, however, are usually concerned with much smaller projects (individual housing estates or parts of urban renewal pro- 
grammes) than in France. Thrift (1994) discusses the public/private partnership in the Netherlands that has led the Randstadt to become a major global metropolis. Van der Valk and Faludi (1992) cite France's 'New Towns' as a model for large-scale partnerships in sustainable urban and economic (re)development.

Planning for the future, Marne-La-Vallée intends to reinforce the office node of Porte de Paris and to distribute widely the spillover effects of the Disneyland Paris resort in Val d'Europe. Phase II of the Disney resort is in its construction stage. The French government has also exported the expertise acquired through experience by the members of the EPAs (établissements publics d'aménagement). They created a groupe d'intéret économique, GIE Villes Nouvelles de France, which, for example, in 1991 at the request of the Chinese, drew plans for the mega-redevelopment of the Lujiazul sector of Shanghai. It is to become the 'city of the twenty-first century', a futuristic financial hub for China and the whole Pacific region (Olds, 1995: 1732).

\section{Part 3: The Role of Local Government}

\section{A. Deregulation and local government involvement}

In the 1960s, policies were conceived and planned by the state and imposed on local communities. After 1976, flexibility was introduced. In 1982-83, the laws of decentralisation 'signalled', not a withdrawal of the state, but a pull-back in favour of local action, financially supported by the state (Clary, 1993: 39) in the form of planning contracts (contrats de plan) between the state and the newly created regions. By the early 1990s the state was disengaging from investing in heavy infrastructure for tourism partly because economic returns were slow in materialising. The recession also reduced the availability of funds so the state could no longer act effectively in all areas. It abandoned the idea of a national purpose in land use control. Local communities now initiate tourism development programmes. Deregulation, however, does not necessarily mean greater autonomy. The market sets its own parameters. Government regulations are not simply restrictive. Planning policy may constrain opportunities but it also creates new ones: 'natural' out door recreation areas exist in Western Europe because governments deliberately protect these areas.

The accent was put on more efficient management of the existing structures and on greater participation by all stakeholders in the projects. A shift had occurred from the acceptable predominance of sovereignty-law-repression to the development and diffusion of more subtle and economic forms of power, exercised over life, over individuals and populations. Foucault explained this shift as 'governmentalisation' of the state whereby sovereignty, the object of which is the preservation of territory became uncoupled from government that focuses on the human condition. The French government has been among the slower ones to adopt this paradigm shift. Three centuries of centralised bureaucracy, reinforced by the tight control required to manage Fordist production mean that, even in its most liberal hour, French capitalism remains in the hands of the state. It has been reluctant to adopt post-Fordist principles of development until forced by recessionary economic circumstances.

The Xth Plan (1989-1993) was to favour destinations returning a high rate of value added rather than those simply increasing the numbers of visitors. The 
social consensus on major infrastructural funding had softened. The new role of the state was to act as designer, coordinator and leader, creating an environment, defining an urban context, and stimulating initiatives. Local actors have been encouraged to respond more effectively to increased competition through improved relations between quality and price. The DATAR has not disappeared. It handles smaller projects and seeks cooperation with the newly established regions. Its objectives are to provide them with the means to develop their comparative advantages within the context of European and world economic competition. It supports, for example, the restoration of grands sites like the Dune du Pyla along the southern Atlantic coast. The state still controls major infrastructural decisions.

The old hegemonic societal paradigm was finally lifted, permitting those competing (non-leftist) ideas that had been in the shadow of the dominant political discourse to become incorporated in the new neo-statist paradigm and to mute their opposition. The state will

'... define and implement programs of national interest, either within a given tourism sector (hotels, for example) or to coordinate large interregional public works, or to act as a lever (subsidizing major studies or promotional programs). The state can also draw broad national policy decisions for the development of tourism. Regions would implement those programs previously started by the state that are of regional interest. They would also coordinate all public decisions in regional tourism development in accord with all other local authorities' (Conseil National du Tourisme (CNT), 1994).

Deregulation has been favoured by many governments but the French state has difficulty relinquishing its authority. In the air transport area it has regrouped its airlines to make them more competitive but has barely opened the French market to foreign competition (Durand et al., 1994). Ile de France gained regional autonomy only after the implementation of the law of 5 July 1993, even though decentralisation policies had been adopted in 1982-83. The state has moved from a visibly active to a more passive and diffuse involvement in the planning and development of tourism. It has reserved the right to develop sites of international repute and those that generate national prestige. In the late 1980s it promoted French culture, its artefacts, and monuments as tourist attractions to be managed competitively with other theme parks and attractions (Monnier, 1987). Castles, monuments and museums that have been registered and/or classified (as described in 1D above) are funded as aspects of cultural heritage.

The state opened the Maison de la France in 1987 as its international promotional arm. It can thus coordinate the marketing actions of the different levels of government as well as those of private operators. It concentrates its marketing efforts on 11 countries: seven in Europe plus the United States, Japan, Canada and Australia. The nation-state and tourism have a natural affinity since both have an interest in constructing a place as unique and distinctive (Wood, 1997). The French state's interest in supporting international promotion through Maison de la France is as much political as economic. Maison de la France has also encouraged local actors and their representatives to participate in the national 'Bonjour' programme (for a friendly welcome of visitors) since its application can 
only occur at the local level by those who actually service visitors. It has, at the same time, invested heavily in some products like Club Mediterranée, Accor, Wagons-Lits, and Visit France through the Caisse des Dépôts et Consignations (the very one who 'subsidised' Eurodisney SCA at below the market loan rates) to create a tourism product mass competitive at the European scale.

Participation in the European Community will force the French state to adopt a more liberal ideology. Europe has become an unavoidable partner so that development programmes cannot exist only at the national scale. Within the context of a spatially expanding European political framework, two main sectors are developing. Greater local and regional autonomy can respond to this development since local authorities should provide more flexible planning procedures and greater knowledge of their environmental strengths. The first sector is that of intra-regional leisure and recreation to satisfy the needs of local populations. Improvements in those areas benefit international visitors too (see nature tourism and river tourism described further on). The second concerns long-haul tourism concentrated along the pleasure periphery of Europe. Sustaining the tourism product in those areas and elsewhere requires constant regeneration and coordination among its different agents.

\section{B. Distribution of competencies between levels of government}

Leadership and vision are important in building local development capacity together with a correct evaluation of the expected benefits. In order to manage its territory the community must come up with a strategy to control investments and land uses that it can oppose to private strategies. Public policy is important and the public sector has a determining role in supporting local economic growth, together with increased cooperation between the public and private spheres in developing policies for the future (Gittell, 1994; Pagano \& Bowman, 1995; Wilson, 1988). These authors also underline the need for a more encompassing local policy than just industrial recruitment. Leadership capacity (i.e. effective institution building and policy-making) seems to be the main prerequisite to insure the viability of contemporary economically productive agglomerations. French administrative partitioning, however, has changed little since départements and communes were created following the 1789 Revolution. The new regions are really only the more recent way of regrouping the départements and they rarely correspond with the present socio-spatial organisation of the country. There has been no attempt to restructure French public administration on the basis of socio-economic regions.

Regional and local authorities are purported to be much closer to regional problems and strengths than central agencies. This 'reconstitution of national and regional governance' (McLeod \& Jones, 1999) is to bring decision making as close as possible to the location affected. It will also provide for more flexible management of the majority of projects, which are of considerably smaller size than the Disneyland resort. The national state is being hollowed out in favour of a resurgence of local and regional governance. It also means that the regional and social redistributive policies of the past are being replaced by supply-side initiatives to promote competitiveness. Although the French state has withdrawn from direct management and sponsorship of many economic projects, it is not withering away. It remains the key site for galvanising political discourse and 
maintaining social cohesion. It has, for example, retained its role of steering the new interorganisational relations of governance.

The retreat of the state has sometimes meant the absence of an organising power for local development, which leads local projects to grow in isolated fashion or to the invasion by large commercial ventures. The reintroduction of a hegemonic model would, however, be inappropriate. The new contracts of cooperation between the state and regions instituted in the $X$ th plan, are a response to the need for the coordination of all levels of governance, coordination best achieved by the regions. The law of 23 December 1992 distributes the role of each layer of governance in tourism development. A 1994 evaluation of tourism development found that in the case of both cultural attractions and natural sites, there had been little attention paid to tourists' needs: signs and facilities to direct, service and welcome visitors were absent (CNT, 1994). National focus on major projects, like the Disneyland resort, had bypassed local requirements. Local communities involved in smaller programmes have thus suffered from lack of economic spillovers.

These inadequacies explain in part the low level of spending of international visitors in France. Few remain more than the one or two days required to cross the country since there were insufficient amenities to delay them. The country received 70 million visitors in 1998 who spent only US\$29.7 billion. The United States, on the other hand, received only 46.4 million visitors but they spent US\$71.1 billion. In Italy 34.8 million visitors spent US\$30.4 billion (Direction du Tourisme, 1999). The millions of visitors to the Loire Valley castles, for example, have fostered little economic activity in the surrounding villages (Bauer, 1993). The state has thus contracted to encourage spending on tourism projects by the various regions, providing 45\% of the FF1.705 million (US\$320 million) allocated in the XIth Plan. This investment is above and beyond that provided by various land developing and activity supporting ministries (such as, for example, subsidies to farmers to develop rural tourism in order to remain on the farm).

Since the vote on decentralisation, the French state has encouraged grass roots development because of the fractal, chaotic and complex nature of tourist activities especially in rural areas and because different organisations have different capacities, roles and responsibilities. It would also avoid stifling creativity, a condition basic to the development of sustainable tourism (Goodey, 1997). It has also recognised the need to support and coordinate a national tourism policy to avoid anarchy and cumulative disinvestments, while encouraging positive synergies. It has remained a major partner even if it now acts backstage rather than on stage. The actions of the French state have confirmed Foucault's perspective on the locations of power: 'Power is not homogeneous but can be defined only by the particular points through which it passes ... power is local because it is never global, but it is not local or localized because it is diffuse' (in Deleuze, 1988: 25-6). Such diffuseness of power enables the state to maintain its presence without visibility.

\section{Limitations of local governments}

Local authorities often depend on the private sector to finance most economic expansion, and they have only very limited tools for attracting expansion. Local authorities also often lack the financial means to implement or to impose their 
perspective on private development plans or must compete with a wide array of localities for few projects. The New Towns in the Paris Basin were all vying for the soccer stadium built for the World Cup, but only one (Sénart) could win. Much investment is in the maintenance of the general infrastructure such as transport arteries or the water supply, which are basic necessities for a quality tourist experience. Some of the programmes contracted for in the XIth Plan mention 'quality' for the first time. Local authorities have, however, little influence individually to direct tourist flows towards specific local attractions even though National Plans designate them as the providers of such products since local specificities do dictate local provision of tourism products.

Local governments must be willing to cooperate and set aside or modify strategies and priorities that are conflicting. Only 30\% of local communities have organised as associations in order to avoid competition: the association collects taxes from the private companies that invest locally and redistributes the revenues to all of its members. Some links have been established to coordinate local and national public authorities because they all have different powers, not perfectly aligned and sometimes jumbled. The law of 2 February 1995 tries to divide clearly the respective competencies at each decision level and to put more precisely some clear limits on the power of local governments. These different levels of government meet several times a year to create synergies and to reach development goals more efficiently. This articulation is extremely important because larger projects generate a multitude of consequences while smaller ones need to avoid duplication.

Although the state seems to withdraw its support (its financial contribution has been judged inadequate (CNT, 1994)), it still requires attention to its original dictates of planning for equity. These contracts must follow five major objectives: modernisation and efficiency, competitivity of French products and production, rural and agricultural development, environment, quality of life and growth, as well as social cohesion and prevention of exclusion (CNT, 1994). Another objective was to facilitate coordination with programmes of the European Community. Transboundary inter-regional cooperation gives regions structuring capacities and greater financial clout than individual regions can muster on their own. The European Community favours such transboundary cooperation as it counteracts individual state sovereignty. It also provided FF1.070 million (US\$170 million) to support such projects over the French Xth Plan, confirming policies sketched in the late 1980s (Akehurst, 1993).

This articulation within the French state apparatus has facilitated some forms of broad and systematic assessment, which underpin many tourism planning decisions, to avoid repeating mistakes, as, for example, in the case of fluvial tourism (see section E below). At the same time, programmes are continued simply because they have been agreed to by local authorities. Regional leaders are reluctant to innovate to avoid rounds of new negotiations with multiple local governments. Policies promoting physical redevelopment through public-private partnerships were heralded as the key to economic success (Fainstein, 1994). Different views exist on the required degree of regulation of these agents (Turner, 1993). Resistance from market interests, the need to ensure the collaboration of multiple agencies, the need for complementary measures and the 
competitive fears amongst local authorities can all tend to diminish the effectiveness of regulation at the local level.

\section{Redistribution of responsibilities in nature tourism}

The organisation of nature tourism illustrates this new division of responsibilities between the different levels of government following the implementation of decentralisation laws. Nature tourism has seen increased numbers of participants because they prefer to spend less profligately on their vacations. Unfortunately, political rivalries often interfere with cooperation, as was illustrated by the distribution of the 1992 Winter Olympics venues over numerous communal sites in the French Alps. At the state level, the Ministry of the Environment, created in 1971, is in charge of national parks, of the protection of specific sites, and the conservation of sea and lake coastal zones. The state has also created natural reserves, some of which it has made accessible to the public, but permanent constructions (including hotels) are prohibited. Access to the parks is paid for through taxation. Their touristic attraction resides in their very existence. The

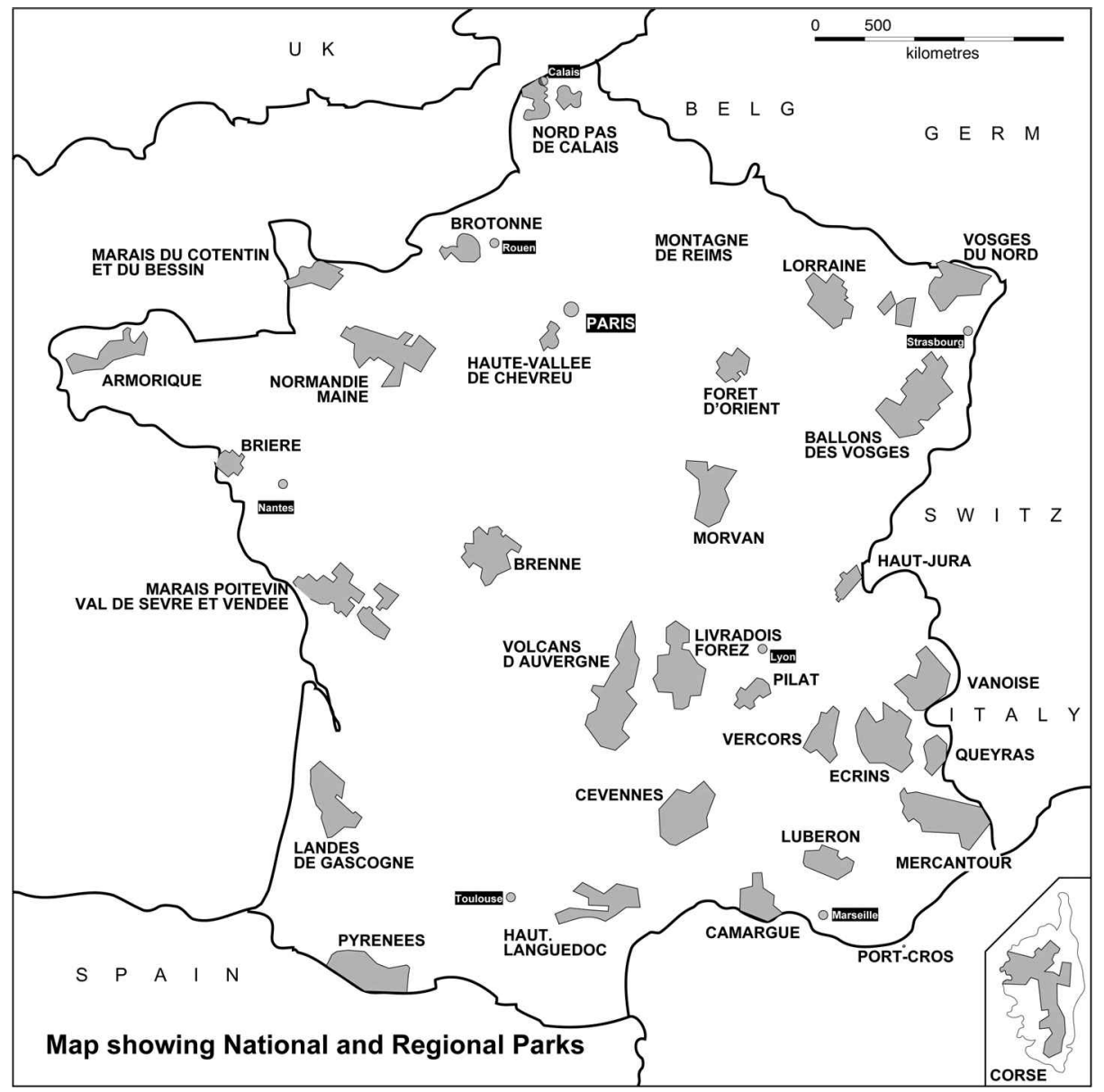

Figure 2 Distribution of National and Regional Parks in France 
French public does not tolerate commoditisation of these 'social' spaces even if it has been proven that visitors are more respectful of facilities they have paid for directly. The state also guarantees the legal strength of regulations concerning environmental protection and conservation.

The French state has established legislation for the protection of natural areas since the ninth century. More recently, laws have been voted since 1913 but they have often been insufficiently applied or enforced. Local authorities have no regulatory powers in environmental matters. Financing is scheduled at the departmental level, but it is unevenly distributed and penalises the more rural areas since earnings come from a tax on construction permits. Financing from the state is available only if the site benefits from special protection statutes. In the early 1990s, the French state adopted a policy of enhancement, through the Ministry of the Environment and the Ministry of Tourism, of certain landscapes, called Grands Sites, to halt their degradation due to poorly organised and excessive visitation. The very existence of these specific sites is socially constructed. Together, they represent the varied landscapes of the 'beautiful French countryside'. Their 'touristification' is a result of their renown which attracts large numbers of visitors, in turn, confirming their 'greatness' and hence their attractivity to ever larger numbers. They are targeted as representative of the whole region they are located in. Their upgrade should benefit their surroundings.

These sites are different from Natural Parks which are considered to be ecological domains, another form of social construction also vulnerable to 'touristification'. The policy is to raise the quality of the grands sites experience through controlled visitor flows, protection of some of its features, organisation of the 'welcome' (parking, information, interpretation, itineraries, and other services) and provision of overnight accommodations nearby. These are needed to ensure economic benefits to the area. The idea of charging for these services is slowly making headway in France. This initiative really aims at encouraging local authorities to band together to maintain and control the grands sites. The partnership can also include all private organisations concerned with the exploitation of the site. The purpose is to generate economic benefits that would then spread over a wide area. These 'Grands Sites' (in 1993, 27 of them had been identified and supported) should become magnets that attract visitors to the region who can then be redirected to other smaller regional attractions (Ministère de l'Environnement, 1993).

The 1982-83 decentralisation laws have given the 22 regions and 96 départements the ability to create regional natural reserves (31 existed in 1996) and to raise taxes to finance their maintenance (for example taxes on certain construction permits). Some départements have set up walking and trekking itineraries through their territories. Posted signs, information kiosks and maps are available to guide users of these trails. Some of the 36,000 local communes $(30 \%)$ have grouped themselves into syndicates of land use management to plan for a more harmonious tourist product both diversified and complementary. A successful tourist product demands a strong regional will to implement the required structures. Thanks to these initiatives, visitors have access to a network of 196 natural reserves (80 of which are local) equipped with guides and centres of interpretation. Lodging is also often available. In 1996 they welcomed 350,000 
visitors. The government's action extends to traditional rural villages to enable them to advertise their vernacular and authentic quality. In 1996,135 belonged to the association Plus Beaux Villages de France.

Nature tourism is complemented by traditional accommodations run privately by individual owners registered with national charts. The chain Logis de France regroups 4000 hotels in rural locations, 90\% of which are in historic buildings well integrated in the traditional 'habitas'. The chain Gites de France offers bed and breakfast in more than 37,000 locations. A chain, St Pierre, specialises in services to devotees of fishing. Walking and trekking associations also have their own lodging services such as Rando-plume. The supply of lodging for tourism purposes in rural areas, as shown by these few examples, is extremely diverse, in part in response to just as variegated a demand. Important investments have been made in this domain over the past 50 years, which have facilitated rural development. The state is advocating the streamlining of their tax status and of their promotion and marketing while it is concerned about the trivialisation of culture in their advertising. Although the government, at all levels, is supportive of tourism, even where it has become the only economic activity, it does underline that it need not remain a single product. A variety of products need to be offered visitors and uniformity must be avoided, especially in new construction. It is more attractive for the visitors as well as for the permanent residents and more sustainable for investors.

\section{E. Organisation of river tourism}

The state took an interest in the tourism vocation of the water network in the late 1980s, when it had already adopted decentralisation policies. It was thus not compelled to invest heavily in its upgrading. Contracts have been signed between several regions (Franche-Comté, Languedoc et Roussillon et MidiPyrénées) and the statein the course of the XIth Plan to encourage river and canal tourism. This activity is best administered at the local level because of its multiple diffused locations and site dependent characteristics. Voies Navigables de France (VNF), which represents the state as landlord and as manager of the network, must coordinate the activities of regional and local operators so that all benefit from such synergy that will generate social and economic well-being in the areas drained by the network. This includes public-private partnerships to increase accessibility to investment funds. VNF was created as a public organisation in 1991.The state has focused on a few select sites for global sustainable development from which it can learn methodologies that will then be applicable to all other sites on the network (Conseil National du Tourisme, 1997).

The navigable river and canal network of France is the longest in Europe: 8500 $\mathrm{km}$. The network was first used as a tourist attraction in 1949 , by the Compagnie des Bateaux-Mouche of Paris. It transports tourists along the Seine River within the city. Usage of the national network doubled between 1980 and 1990, but has remained unchanged since. Attractions include the Canal du Midi which has been classified as a World Heritage Site, the Briare Bridge-Canal, the Canal of Burgundy as well as the varied but fragile landscapes these waters flow through. The network's tourism value has led to government support only belatedly. In the period 1988 to 1992 the government did cancel projects such as dams on the Loire River. The state had financed infrastructure but according to a public 
works logic so that size and location rarely corresponded with the needs. These mistakes have led Voies Navigables de France to seek partnerships with private developers as well as with local governments, although it means loss of control or outright loss of property for VNF (CNT, 1997).

Securing funding for this form of rural tourism has been difficult in spite of its attractiveness. Rehabilitation of the network is financed by user fees and state subsidies but they are insufficient to cover expenses caused by several decades of neglect and numerous demands by a multiplicity of users, not all tourists or tourism promoters. The quality of the water needs to be upgraded and pollution sources closed. River banks and their immediate environments must be maintained. Tourist and navigation safety information needs to be widely diffused in an aesthetic manner. Many parts of the network will have to be transformed from merchandise hauling to tourist promenading, with landing and launching pads and picnic areas. Sustainable development of fluvial tourism will require both private investments and proper regulatory measures that are best organised at the local level. Regional authorities could use a reflexive focus on the development of the riverine environment as a lever for integrating all stakeholders, especially communes and départements in local economic growth. Such growth should include more than just tourism development.

\section{Conclusion}

France has a unitary, centralised government, which decides tourism policy at the national level, even if efforts have been made to decentralise government activity. Implementation of French public policy is highly complex in that it involves many actors, different levels of action and authority, and many types of policy instruments. Much tourism development is subject to regulatory bodies created independently of tourism concerns, such as aviation and transport, labour relations, hotel construction and management. It is thus often difficult to draw a line between the public and the private sector (Lanfant, 1980) even if the ideology of consumer sovereignty lends support to the idea that state intervention, which connotes domination and control, should be kept out of tourism development (Wilson, 1988). The presence of the French state will continue to pervade the tourism industry, which includes enabling the participation in travel by economically disadvantaged persons. It has been active in both a managerial way (it has set objectives for tourism and it has introduced organisational and legislative support to attain these) and in a developmental one (through financing infrastructure and facilities that receive visitors or through the provision of specific policies in favour of the tourism sector).

The implementation of the Disneyland Paris project would have been impossible without the redistributive ideology of the French government. The contract signed by the Walt Disney Company in 1987 depended on the convergence of the strategies of both parties. The French government could never have forced the Disney Company to implant a resort in Marne-La-Vallée. The Paris Basin was attractive to the Walt Disney Company because it depends on agglomeration forces and on a well articulated infrastructure for its successful operation. This merging of strategies justified the public assistance that the Walt Disney Company (which was bringing in large private investments) benefited from for 
its implantation in France. This public help enabled the government to offer a 'new institutional space' (Jones, 1999), a well-serviced, large acreage of land within a relatively short time so that only five years passed between the signing of the Convention and the opening of the park.

The French state tamed the 'profit-seeking adventurism of the private sector' (Amin \& Malmberg, 1994: 244) even though the French government was relying more on a managerial model (with greater reliance upon private-sector-led efforts) of neostatist spatial governance, than a social(ist) one. This circuit of tourism capital had been reined in so that it could not abandon the Francilian landscape at the first sign of diminished returns and leave a derelict environment. The size of the company's investment, but even more so its knowledge, made it a potential engine for stimulating new growth. The state found a new niche that the eastern suburbs of Paris could occupy on the global economic scene. Spillover effects have been positive for the French government and society from the day the park opened its gates, and even while it operated in the red (d'Hauteserre, 1997). In 1998, it generated FF21 billion (US\$3.2 billion) of secondary and later economic spillovers in the Ile de France region. National and European territorial equalisation have hardly been enhanced, but the position of Paris as a major participant in the global (tourism) economy has. It thus answered the VIth Plan's first goal (DATAR, 1970).

Although the state has relinquished its hold even on the region surrounding Paris, this region still benefits from earlier plans and the projects they captured. The 1992 plan (SDAURP, 1992) considered the land use management of the region at a supra-national scale to capitalise on its incorporation within the European Union. It leads the world, for example, in the number of international congresses. Its main drawing card is its integration in international networks of exchanges and contacts, integration reinforced by the local articulation of air links with rapid trains (European and French network) and with the RER (local public transport links). Its role is of a plaque tournante for transport and tourism. Roissy is one of the major aerocities of modern times (Robert, 1994: 117). It is also the only large European airport which still has vast expansion capacities. In 1999, Eurodisney SCA started on the second part of its 30 year development project in sector IV of Marne-La-Vallée, as planned in 1987: the project includes a major commercial centre $\left(90,000 \mathrm{~m}^{2}\right)$, a second theme park which is scheduled to open in 2002, housing, and transport infrastructure, supporting the continued economic vitality of the Parisian Basin.

One of the problems future tourism projects will face is that many local public officials still believe that tourism provides economic benefits with little investment. Public funds remain scarce. Another problem is that of spatial structuration: tourism spaces rarely correspond with social spaces. Inhabitants rarely recognise their aspirations in spaces organised as tourist destinations. The main weaknesses stem from organisational modes too typically French. Some of the success stories of French planning for tourism development in the face of an increasingly competitive and globalising political economy are also based on highly contingent social, institutional, and cultural arrangements. Globalisation and transnationalisation are not unidirectional forces that constrain 'local' agents in similar ways. Different strategy mixes occur in particular spaces at specific times, depending on historical, economic, political, or socio-spatial 
forces. The French state has treated tourism as an integral part of the social relations in which they occur even as it has encouraged tourism as a motor of economic development, which it has also helped to diversify. Perhaps most importantly, it has not lost sight, either, of the need to preserve, improve even, French cultural identity in an evolving geopolitical context.

\section{Correspondence}

Any correspondence should be directed to A-M. d'Hauteserre, Co-ordinator of Tourism Studies, Department of Geography, University of Waikato, Private Bag 3105, Hamilton, New Zealand (adhautes@waikato.ac.nz).

\section{References}

Akehurst, G. (1993) European Community tourism policy. In P. Johnson and B. Thomas (eds) Perspectives on Tourism Policy. London: Mansell.

Altvater, E. (1993) The Future of the Market: Essays on the Regulation of Money and Nature after the Collapse of Actually Existing Socialism. London: Verso.

Amin, A. and Malmberg, L. (1994) Competing structural and institutional influences on the geography of production in Europe. In A. Amin (ed.) Post-Fordism-A Reader (pp. 227-47). Oxford: Blackwell.

Apthorpe, R. (1997) Writing development policy and policy analysis. In C. Shore and S. Wright (eds) Anthropology of Policy. London: Routledge.

Ascher, F. (1994) Le Partenariat Public-Privé Dans le (Re)développement: Le Cas de la France in Partenariat Public-Privé dans l'Aménagement Urbain. Paris: L'Harmattan.

Baleste, M. (1989) L'Economie Française. Paris: Masson, Collection Géographie.

Bassett, K. (1996) Partnerships, business elites, and urban politics: New forms of governance in an English city. Urban Studies 33 (3), 539-55.

Bauer, M. (1993) Tourism in France. In W. Pompl and P. Lavery (eds) Tourism in Europe. Wallingford: CAB International.

Bauer, M. (1996) Cultural tourism in France. In Greg Richards (ed.) Cultural Tourism in Europe (pp. 147-64). Wallingford: CAB International.

Beauregard (1990) Bringing the city back in: The ambiguous position of US planning. Society and Space 7, 381-95.

Bennett, R. and Estall, R. (eds) (1991) Global Change and Challenge. London: Routledge.

Burlet, G. (1987) Euro Disneyland-du Rêveà la Réalité. Conseil Général de Seine et Marne.

CEDAET (1992) Le Tourisme Social et Familial. Paris: La Documentation française.

Comité National Français de Géographie (CFNG) (1996) Les Français dans Leur Environnement. Paris: Nathan.

Clary, D. (1993) Le Tourisme dans l'Espace Français. Paris: Masson.

Conseil National du Tourisme (1994) Bilan des Contrats de Plan État-Régions 1989-1993 et Perspectives pour le Tourisme dans le XIè Plan. Paris: Ministère de l'Equipement, des Transports et du Tourisme.

Conseil National du Tourisme (1997) Le Tourisme Fluvial, Section de l'Aménagement Touristique. Paris: La Documentation française.

Convention (1987) Paris: Département de Seine et Marne (28 March).

CREDOC (1992) L'État de la France. Paris: La Découverte.

DATAR (1970) Commission d'Aménagement du Territoire. Paris: Ministère de la Planification, Sixth Plan.

Delouvrier, P. (1966) Quoted in GIE Villes Nouvelles de France (1993), 42.

Deleuze, G. (1988) Foucault (trans. and edited by Sean Hand). London: Athlone Press.

d'Hauteserre, A-M. (1997) Disneyland Paris: A permanent growth pole in the Francilian landscape. Progress in Tourism and Hospitality Research 3 (1), 17-33.

d'Hauteserre, A-M. (1999) The French mode of social regulation and sustainable tourism development: The case of Disneyland Paris. Tourism Geographies 1 (1), 86-107.

Direction du Tourisme (1999) Mémento du Tourisme. Paris: Observatoire National du Tourisme. 
Durand, H., Gouirand, P. and Spindler, J. (1994) Economie et Politique du Tourisme. Paris: Librairie Générale de Droit et de Jurisprudence.

EPAFrance (1994) Note de synthèse: le partenariat public-privé dans le projet EuroDisneyland. Noisiel.

EPAMame (1987) Projet d'Intérêt Général Relatif au Secteur IV de Marne-La-Vallée. Noisiel.

EPAMame (1988) Etude d'Impact de la Première Phase de I'Euro Disneyland. Noisiel.

Eudes. Y. (1992) Les cadeaux de la France. Le Monde Diplomatique (19 Aug).

Eurodisney Resort (1993) Eurodisney, les Éléments-Clés à Connaître, March. Paris.

Fainstein S. (1990) The changing world economy and urban restructuring. In D. Judd and M. Parkinson (eds) Leadership and Urban Regeneration (pp. 31-47). London: Sage.

Fainstein S. (ed.) (1994) City Builders. New York: Blackwell.

Flower, J. (1991) Prince of the Magic Kingdom. New York: John Wiley.

Friedmann, J. (1987) Planning in the Public Domain. Princeton, NJ: Princeton University Press.

Gaudin, J-P. (1985) L'avenir en plan. Paris: Champ Vallon.

GIE Villes Nouvelles de France (1993) Twenty Five Years of French New Towns (trans. Alan Lee). Jean-Eudes Roullier, chairperson. Paris.

Gittell, R.J. (1994) Renewing Cities. Princeton, NJ: Princeton University Press.

Goodey, B. (1997) Les projets de développement durable: Principaux partenaires. In Conseil de l'Europe (ed.) Développement Touristique Durable: Conciliation des Intérêts Économiques, Culturels, Sociaux, Scientifiques et Environnementaux. Strasbourg: Conseil de l'Europe.

Grover, R. (1991) The Disney Touch. New York: Irwin.

Hastings, A. (1996) Unraveling the process of 'partnership' in urban regeneration policy. Urban Studies 33 (2), 253-68.

IAURIF (1988) Effets Prévisibles de l'Euro Disneyland dans son Environnement de Seine et Marne. Paris.

Jones, M. (1999) New Institutional Spaces: TECs and the Remaking of Economic Governance. London: Jessica Kingsley.

Journal Officiel Senat (1994) Rapport sur le Projet de Loi de Finances pour 1994. Paris: Documents parlementaires, 101.

Judd, D. and Parkinson, M. (eds) (1990)Leadershipand Urban Regeneration. London: Sage.

Lanfant, M.L. (1980) International tourism resists the crisis. In A. Olszewska and K. Roberts (eds) Leisure and Lifestyle: A Comparative Analysis of Free Time. London: Sage.

Lanquar, R. (1992) L'Empire Disney. Paris: Presses Universitaires de France.

Lanquar, R. (1995) Tourisme et Environnement en Méditerranée. Paris: Economica.

Lipietz A. (1987) Eurodisneyland, un projet sans intérêt public? Etudes Foncières 34 (3-8 March).

Livre Blanc du Bassin Parisien (1992) Paris: La Documentation française.

McLeod, G. and Jones, M. (1999) Reregulating a regional rustbelt: Institutional fixes, entrepreneurial discourse, and the 'politics of representation.' Environment and Planning D 17 (5), 575-605.

Meiksins Wood, E. (1995) Democracy against Capitalism. Cambridge: Cambridge University Press.

Ministère de l'Environnement et Ministère du Tourisme (1993) Environnement et Tourisme. Paris: La Documentation française.

Ministère de l'Environnement (1995) L'Environnement Méditerranéen. Paris: La Documentation française.

Monnier, B. (1987) Un projet pour Versailles. In L'enjeu touristique, parliamentary documents. Journal Officiel 968, 65.

Observatoire National du Tourisme (1998) Le Tourisme Social, Associatifet Corporatif. Paris: Secrétariat d'Etat au Tourisme.

Olds K. (1995) Globalization and the production of new urban spaces: Pacific Rim mega-projects in the late 20th century. Environment and Planning A 27, 1713-43.

Pagano M. and Bowman, A. (1995) Cityscapesand Capital: The Politics of Urban Development. Baltimore: Johns Hopkins Press. 
Patin, V. (1997) Tourisme et Patrimoine en France et en Europe. Paris: La Documentation française.

Peck, J. and Tickell, A. (1995) The social regulation of uneven development: 'Regulatory deficit', England's south east, and the collapse of Thatcherism. Environment and Planning A 27, 15-40.

Ploegaerts, L. (1986) French new towns and urban innovation. Canadian Geographer30 (4), 324-36.

Poujol, G. (1993) Leisure politics and policies in France. In P. Bramham, I. Henry, H. Mommaas and H. van der Poel (eds) Leisure Policies in Europe (pp. 13-40). Wallingford: CAB International.

Poulantzas, N. (1978) State, Power, Socialism. London: Arnold.

Py, P. (1996) Le Tourisme. Paris: La Documentation française.

Rapport Général de la Commission du Tourisme (1965) Vème Plan. Paris: La Documentation française.

Rapport de la Commission du Tourisme (1971) Vlème Plan. Paris: La Documentation française.

Rencontres (1992) La Gestion Territoriale des Grands Aménagements de Loisirs. Paris: Ed Van Wilder.

Robert, J. (1994) L'Ile de France. Paris: Presses Universitaires de France.

Robert, M-M. (1990) Faut-il avoir peur de Disney? E.M.H. 1, Paris (April).

Rochefort, M. (1996) Dynamique de l'Espace Français et Aménagement du Territoire. Paris: l'Harmattan.

SDAURP (1966) Schéma Directeur d'Aménagement et d'Urbanisme de la Région de Paris, 1965. Paris: La Documentation française illustrée.

SDAURP (1992) Projet de Schema Directeur pour l'Ile de France. Paris: Les Editions Porte Plume.

SETEC $(1985,1986,1987)$ Impact socio-économique de l'implantation du projet de MarneLa-Vallée.

Smadja G. (1987) Mickey l'Arnaque. Paris: Messidor.

Storper, M. (1997) The Regional World. New York: Guilford.

Storper, M. and Scott A. (eds) (1992) Pathways to Industrializationand Regional Development. London: Routledge.

Thrift, N. (1994) Globalization, regulation, urbanization: The case of the Netherlands. Urban Studies 31, 365-80.

Tuppen, J. (1991) France: The changing character of a key industry. In A.M. Williams and G. Shaw (eds) Tourism and Economic Development: Western European Experiences (2nd edn) (pp. 191-206). London: Belhaven Press.

Turner, R.K. (ed.) (1993) Sustainable Environmental Economics and Management: Principles and Practice. London: Belhaven.

Vachez (1989) A local elected official, quoted in Rencontres (1992: 52).

Van der Valk, A. and Faludi, A. (1992) Growth regions and the future of Dutch planning doctrine. In M. Breheny (ed.) Sustainable Development and Urban Form (pp. 122-37). London: Pion.

Violier, P. (1999) L'espace Local et les Acteurs du Tourisme. Rennes: Presses Universitaires de Rennes.

Walker, R.A. (1995) Regulation and flexible specialization as theories of capitalist development: Challenges to Marx and Schumpeter. In Liggett and Perry (eds) Spatial Practices: Critical Explorations and Social Spatial Theory (pp. 167-208). London: Sage.

Wilson, J. (1988) Politics and Leisure. Boston: Unwin Hyman.

Wood, R. E. (1997) Tourism and the State: Ethnic options and constructions of otherness. In M. Picard and R.E. Wood (eds) Tourism, Ethnicity, and the State in Asian and Pacific Societies (pp. 1-34). Honolulu: University of Hawai'i Press. 